\title{
Effect of intrafollicular indomethacin injection on gonadotropin surge-induced expression of select extracellular matrix degrading enzymes and their inhibitors in bovine preovulatory follicles
}

\author{
Qinglei $\mathrm{Li}^{1,2}$, Fermin Jimenez-Krassel ${ }^{1,2,4}$, Yasuhiro Kobayashi ${ }^{1,2}$, James J Ireland ${ }^{2-4}$ and \\ George W Smith ${ }^{1-3}$ \\ ${ }^{1}$ Laboratory of Mammalian Reproductive Biology and Genomics, Departments of ${ }^{2}$ Animal Science and \\ ${ }^{3}$ Physiology, ${ }^{4}$ Molecular Reproductive Endocrinology Laboratory, Michigan State University, East Lansing, \\ MI 48824, USA
}

Correspondence should be addressed to G W Smith at 1230D Anthony Hall, Michigan State University, East Lansing, MI 48824, USA; Email: smithge7@msu.edu

\begin{abstract}
A growing body of evidence supports an obligatory role for intrafollicular prostanoids in the mechanism of ovulation. However, the prostanoid-dependent mediators of the follicular extracellular matrix degradation required for ovulation are unknown. The objectives of this study were to determine the cellular compartment(s) in which the gonadotropin surgeinduced regulation of select extracellular matrix degrading enzymes and their cognate inhibitors occurs in bovine preovulatory follicles, and to test whether such regulation is blocked by intrafollicular administration of the prostanoid synthesis and ovulation inhibitor, indomethacin (INDO). Follicular fluid prostaglandin $\mathrm{E}_{2}$ concentrations were elevated in diluenttreated follicles before ovulation ( $24 \mathrm{~h}$ after $\mathrm{GnRH}$ injection), but the increase was blocked in INDO-treated follicles. Realtime PCR analysis revealed the specific follicular cell types where gonadotropin surge-induced increases in mRNA abundance for members of the matrix metalloproteinase/tissue inhibitor of metalloproteinase and plasminogen activator families occurred. INDO treatment increased thecal cell mRNA for tissue inhibitor of metalloproteinase- 4 and its protein abundance in the apex of preovulatory follicles before ovulation, but suppressed granulosal cell mRNA and activity for tissue plasminogen activator in follicular fluid and the follicle apex. Plasmin activity was also suppressed in the follicular fluid of INDO-treated follicles. Effects of INDO injection on select matrix metalloproteinases were not observed. The results suggest that gonadotropin surge-induced regulation of tissue inhibitor of metalloproteinase-4 and tissue plasminogen activator may be prostanoid dependent, and support a potential role for increased tissue plasminogen activator expression and decreased tissue inhibitor of metalloproteinase-4 expression in the mechanism of ovulation.

Reproduction (2006) 131 533-543
\end{abstract}

\section{Introduction}

One of the hallmarks of ovulation is the extensive tissue remodeling that occurs at the follicular apex versus the base (Murdoch \& McCormick 1992). The preovulatory luteinizing hormone $(\mathrm{LH})$ surge initiates a cascade of proteolytic activity controlling the tissue-remodeling process during ovulation (Robker et al. 2000). Two principal families of proteolytic enzymes, the matrix metalloproteinases (MMPs) and the plasminogen activators (PAs)/plasmin, are implicated in the tissue remodeling accompanying the ovulatory process (Smith et al. 2002). The MMPs are a comprehensive family of at least 28 zinc-containing endopeptidases, which can be classified into collagenases, gelatinases, stromelysins, membrane type and other MMPs by their structure, substrate specificity and subcellular distribution (Nagase \& Woessner 1999, Curry \& Osteen 2003). The activity of MMPs in the extracellular milieu is regulated by their tissue inhibitors (TIMPs 1-4), which bind reversibly to MMPs in a 1:1 stoichiometry and inhibit their activity (Gomez et al. 1997, Brew et al. 2000, Murdoch \& Gottsch 2003). The PA system consists of the ubiquitous zymogen plasminogen, which can be activated to the proteolytic enzyme plasmin by two distinct forms of PA (tissue-type PA (tPA) and urokinase-type PA (uPA)) (Tsafriri \& Reich 1999, 
Ny et al. 2002). PA activity is regulated by specific PA inhibitors (PAI-1 and PAI-2) and the urokinase receptor (UPAR), a cell-surface glycoprotein that binds both PAs (Plow et al. 1986, Ny et al. 2002) and focalizes plasmin activity to the cell surface or pericellular space. In addition to a direct role in extracellular matrix (ECM) degradation (Mignatti et al. 1986, Alexander \& Werb 1991), plasmin can activate the pro-form of several MMPs (DeClerck \& Laug 1996, Murphy et al. 1999), underscoring the potential for synergism/cooperativity between the two proteinase families during the ovulatory process.

Prostanoids play an obligatory role in the ovulatory process in numerous species (Murdoch et al. 1986, Dinchuk et al. 1995, Lim et al. 1997, Mikuni et al. 1998), including cattle (De Silva \& Reeves 1985, Peters et al. 2004). The cyclooxygenase (COX)-2 enzyme, which catalyzes the rate-limiting step in intrafollicular prostanoid synthesis, is induced within the granulosal layer of rat (Sirois et al. 1992), equine (Sirois \& Dore 1997) and bovine preovulatory follicles (Sirois 1994, Tsai et al. 1996) in response to the LH surge. Indomethacin (INDO), an inhibitor of the COX pathway, is a potent inhibitor of ovulation in numerous species (Tsafriri et al. 1972, Murdoch et al. 1986, Sogn et al. 1987), including cattle (De Silva \& Reeves 1985). Mice with a targeted mutation in the COX-2 gene are infertile (Dinchuk et al. 1995) and anovulatory (Davis et al. 1999), potentially due to a proteoglycan synthesisrelated alteration in cumulus expansion and impaired follicle rupture. Despite the well-established role of prostanoids in ovulation, the downstream mediators of prostanoid-stimulated follicle rupture remain largely undefined, especially in monotocous species such as cattle. However, several lines of evidence indicate that prostanoids are potent regulators of various MMP and PA system components in other cell types/model systems (Strickland \& Beers 1976, Liu et al. 2001, Negoro et al. 2002, Ito et al. $2004 a, b)$. For example, prostanoid regulation of MMP-13 was reported previously in mouse calvarial cultures, and prostaglandin $(\mathrm{PG}) \mathrm{E}_{2}$-induced $\mathrm{MMP}-13$ production was impaired in calvarial cultures from $\mathrm{EP}_{4}\left(\mathrm{PGE}_{2}\right.$ receptor subtype)-knockout mice (Miyaura et al. 2000).

We have previously reported increased expression of several key MMP and PA system components in bovine preovulatory follicles following the gonadotropin surge, including MMP-13 (Bakke et al. 2004), MMP-14 (Bakke et al. 2002), TIMPs 1-4 (Bakke et al. 2002, Li et al. 2004), tPA, uPA, uPAR (Dow et al. 2002a), PAI-1 and PAI-2 (Smith et al. 1996, Dow et al. 2002b). Furthermore, the preovulatory regulation of MMP-28 in bovine follicles remains undefined. MMP-28, or epilysin, is one of the most recently identified MMPs and belongs to the MMP-19 subfamily of the MMP superfamily (Lohi et al. 2001, Marchenko \& Strongin 2001). MMP-28 has been implicated in several physiologic events including embryo implantation (Li et al. 2003), but its role in the ovulatory process is not known. In addition, the intrafollicular cell types where gonadotropin surge-induced regulation of the above enzymes and inhibitors takes place are unclear. The above studies of changes in mRNA abundance after the gonadotropin surge were conducted with RNA isolated from whole follicles, and changes in mRNA abundance in individual cell types were not examined. Furthermore, in view of the obligatory involvement of prostanoids and ECM proteolysis in the ovulatory process, we hypothesize that the above regulators of ECM remodeling are potential downstream mediators of prostanoid-induced follicle rupture. The objectives of the current study were to determine:

- the cellular compartments (granulosal cells and/or thecal cells) in which the gonadotropin surgeinduced regulation of the above select ECM degrading enzymes and their cognate inhibitors occurs in bovine preovulatory follicles

- whether the above regulation is blocked by intrafollicular administration of the prostanoid synthesis and ovulation inhibitor INDO in dairy cattle.

\section{Materials and Methods}

\section{Animal care and experimental model}

All animal procedures were approved by the All University Committee on Animal Use and Care at Michigan State University. The experimental model utilized in this study has been described elsewhere (Bakke et al. 2002, 2004). Follicular development and timing of the preovulatory gonadotropin surge were synchronized in nonlactating Holstein cows by the Ovsynch (GnRH-7d-PGF $2 \alpha^{-36-h-}$ $\mathrm{GnRH}$ ) procedure (Pursley et al. 1995, 1997) with a slight modification. Briefly, gonadotropin-releasing hormone $(\mathrm{GnRH})$ was injected to start a new wave of follicular growth and thus a new dominant follicle. Then, $\mathrm{PGF}_{2 \alpha}$ was given to regress the corpus luteum 6.5 days later. A second $\mathrm{GnRH}$ injection was given $36 \mathrm{~h}$ later to induce a gonadotropin surge resulting in ovulation of the new dominant follicle. Synchronized ovulation of the dominant follicle occurs an average of $29 \mathrm{~h}$ after the second $\mathrm{GnRH}$ injection (Pursley et al. 1995). Daily ultrasound analyses were performed after the first GnRH injection until the time of follicle collection to verify follicle synchrony and to exclude animals that exhibited a new follicular wave prior to the second GnRH injection (two animals were excluded) or follicles that collapsed after intrafollicular injection (no animals were excluded). INDO, in a volume of $100 \mu \mathrm{l}$ $(200 \mu \mathrm{g} / \mathrm{ml}$ final intrafollicular concentration), or the same volume of PBS (control; CON) was injected into preovulatory follicles immediately after the second $\mathrm{GnRH}$ injection by previously described ultrasound-mediated intrafollicular injection procedures (Peters et al. 2004). The dose of INDO selected was determined by the results of a preliminary dose-response experiment that compared the ability of various doses of INDO $(0,200$ and $1000 \mu \mathrm{g} / \mathrm{ml})$ to block gonadotropin surge-induced increase in follicular fluid (FF) $\mathrm{PGE}_{2}$ measured at $24 \mathrm{~h}$ after $\mathrm{GnRH}$ ( $n=5$ per treatment). 
The concentration of INDO to administer intrafollicularly (in $100 \mu$ l volume) in each individual follicle to achieve the desired FF concentration was calculated mathematically after ultrasonagraphic measurement of follicle diameter immediately before injection.

\section{Sample collection and preparation}

Ovaries containing preovulatory follicles were collected (under epidural anesthesia) by colpotomy (Drost et al. $1992)$ at $0(n=5), 12(\mathrm{CON} ; n=3)$ and $24 \mathrm{~h}$ (INDO and $\mathrm{CON} ; n=5$ each) after the second $\mathrm{GnRH}$ injection. Because of the time course of induction of the COX-2 enzyme (Sirois 1994) and accompanying increase in FF $\mathrm{PGE}_{2}$ (Peters et al. 2004), INDO-treated follicles were not collected at $12 \mathrm{~h}$ after $\mathrm{GnRH}$ injection. FF was harvested from each follicle by aspiration and centrifugation to remove possible blood cell contamination. INDO was then added to FF to achieve a final concentration of $3.6 \mu \mathrm{g} / \mathrm{ml}$ before being frozen on dry ice and stored at $-80^{\circ} \mathrm{C}$. INDO was added, according to the manufacturer's recommendations for $\mathrm{PGE}_{2}$ assay (see below), to prevent ex vivo generation of eicosanoids. To examine changes in mRNA abundance for genes of interest within specific follicular cell compartments during the preovulatory period, follicles were dissected as described elsewhere (Bakke et al. 2002, $\mathrm{Li}$ et al. 2004) and then sagittally cut into four portions (approximately $3-5 \mathrm{~mm}$ wide) containing both apex and base. Granulosal cells (GC) and thecal tissue (TC) were isolated from one portion. GCs were scraped and collected by centrifugation, while TC was isolated by dissection from a portion of the follicle. A volume of $1 \mathrm{ml}$ TRIzol (Life Technologies, Gaithersburg, MD, USA) was added to the GC immediately after collection. Both GC and TC were snapfrozen in liquid nitrogen and stored at $-80^{\circ} \mathrm{C}$ for total RNA isolation and real-time PCR assay. Since the ECM degradation characteristic of the ovulatory process occurs primarily in the follicle apex, we were interested to know whether regulation of protein/activity for select ECM degrading enzymes/inhibitors was specific to the follicle apex versus the base. A second portion of the same follicles was separated into two equal subportions (containing the follicle apex or base) as previously described (Dow et al. $2002 a)$, snap-frozen separately and kept at $-80^{\circ} \mathrm{C}$ for protein extraction.

\section{FF $P G E_{2}$ assay}

Concentrations of $\mathrm{FF} \mathrm{PGE}_{2}$ were analyzed by a previously described (Peters et al. 2004) $\mathrm{PGE}_{2}$ EIA (Cayman Chemical, Ann Arbor, MI, USA). FF was diluted 1:50 in EIA buffer before analysis. Intra- and interassay coefficients of variation $(\mathrm{CV})$ were $5.3 \%$ and $3.1 \%$ respectively. According to the manufacturer, the assay displays $<18.1 \%$ crossreactivity with $\mathrm{PGE}_{1}$ and $<0.1 \%$ cross-reactivity with other prostanoids.

\section{RNA isolation and reverse transcription}

Total RNA was extracted from GC and TC of bovine preovulatory follicles with TRIzol reagent. The yields of RNA were measured by spectrophotometry at $260 \mathrm{~nm}$, and the integrity was evaluated by examination of intensity of $28 \mathrm{~S}$ and $18 \mathrm{~S}$ ribosomal RNA bands on a nondenaturing agarose gel. To eliminate possible genomic DNA contamination, $1 \mu \mathrm{g}$ total RNA from each sample was incubated for $15 \mathrm{~min}$ at $25^{\circ} \mathrm{C}$ with $1 \mathrm{U}$ DNase I (Invitrogen) before reverse transcription. The protocol for reverse transcription using Superscript RNase $\mathrm{H}^{-}$Reverse Transcriptase (Invitrogen) was described previously (Li et al. 2004). The concentration of the resulting cDNA in each sample was determined by spectrophotometry. Each sample was diluted to 100 and $10 \mathrm{ng} / \mu \mathrm{l}$ in nuclease-free water (Ambion, Austin, TX, USA) and kept at $-20^{\circ} \mathrm{C}$ for realtime PCR analysis.

\section{Real-time PCR}

Real-time PCR primers were designed with Primer Express software (Primer Express, Applied Biosystems, Foster City, CA, USA). The optimal primer ratio and the amount of CDNA used were determined in a preliminary experiment. The primers used in this study are listed in Table 1. The amplifications were performed in a 96-well optical plate (Applied Biosystems) in $25 \mu \mathrm{l}$ reaction volume containing $12.5 \mu \mathrm{l}$ SYBR Green PCR Master Mix (Applied Biosystems), $20 \mathrm{ng}$ cDNA samples, the appropriate amount of primers (Table 1) for each gene and nuclease-free water. Nontemplate controls (RNase-free water) for each primer set were included. The real-time PCR reaction was carried out on an ABI Prism 7000 Sequence Detection System (Applied Biosystems) using the thermal cycler program consisting of 40 cycles of $95^{\circ} \mathrm{C}$ for $15 \mathrm{~s}$ and $60^{\circ} \mathrm{C}$ for $1 \mathrm{~min}$. The quantification was performed by the comparative threshold cycle (CT) method established by Livak and Schmittgen (2001). The amount of transcripts for each gene was normalized to the endogenous reference (RPL-19 mRNA). The mean CT of each gene analyzed and endogenous control was calculated for each sample from duplicate wells. $\triangle C T$ was produced by subtracting the mean $\mathrm{CT}$ of RPL-19 from the CT of each target gene. Fold changes in the relative mRNA abundance for target genes in 12- and 24-h samples relative to $0 \mathrm{~h}$ were determined by the following formula: $2^{-\Delta \Delta C T}$, where $\Delta \Delta C T=\Delta \mathrm{CT}_{12 \text {-or } 24 \text {-h sample }}-\Delta \mathrm{CT}_{0 \text {-h }}$ sample. A similar amplification efficiency of target genes relative to endogenous reference (RPL-19) was determined in preliminary validation experiments. Pooled samples of TC and GC cDNA were used. Five serial dilutions of cDNA from pooled samples (2.5, 5, 10, 20 and $40 \mathrm{ng}$ ) were assayed for individual target genes and for RPL-19, and parallel slopes for amplification profiles for target genes of interest relative to RPL-19 confirmed. 
Table 1 Real-time RT-PCR primer sequences utilized for quantification of mRNA for select extracellular matrix degrading proteinases and their cognate inhibitors.

\begin{tabular}{|c|c|c|c|}
\hline Gene name & GenBank acession no. & Primer sequence & $*$ Primer ratio $(\mathrm{nM} / \mathrm{nM})$ \\
\hline MMP-13 & AF072685 & $\begin{array}{l}\text { Forward: GCAGAGAGCTACCTGAAATCATACTACT } \\
\text { Reverse: AATCACAGAGCTTGCTGCAGTTT }\end{array}$ & $300 / 300$ \\
\hline MMP-14 & AF290429 & $\begin{array}{l}\text { Forward: CCTCAACCCAGGACCACTTC } \\
\text { Reverse: GGCCCGTAGGTGGGATTTT }\end{array}$ & $300 / 300$ \\
\hline MMP-28' & XM_583321 & $\begin{array}{l}\text { Forward: CAGGGAAGGCGTCCAGAA } \\
\text { Reverse: CAGTGACGGCATCGAAGGA }\end{array}$ & $300 / 900$ \\
\hline TIMP-1 & M60073 & $\begin{array}{l}\text { Forward: GCACATCACCACCTGCAGTT } \\
\text { Reverse: CCGGCGCTGAGCAGAA }\end{array}$ & $50 / 50$ \\
\hline TIMP-2 & AF144764 & $\begin{array}{l}\text { Forward: GGGCTGTGAGTGCAAGATCA } \\
\text { Reverse: CTCGTCCGGAGAGGAGATGTAG }\end{array}$ & $300 / 300$ \\
\hline TIMP-3 & U77588 & $\begin{array}{l}\text { Forward: GATGTACCGAGGATTCACCAAGA } \\
\text { Reverse: TTAAGGCCACAGAGACTTTCAGAA }\end{array}$ & $300 / 900$ \\
\hline TIMP-4 & AF037273 & $\begin{array}{l}\text { Forward: GAAAGTCTGAATCACCGCTACCA } \\
\text { Reverse: CAGGGCACCGCATAGCA }\end{array}$ & $900 / 300$ \\
\hline tPA & X85800 & $\begin{array}{l}\text { Forward: ACGTCAGGTTGTACCCATCCA } \\
\text { Reverse: GTTGTTGGTGACGGTCCTGTT }\end{array}$ & $300 / 300$ \\
\hline uPA & X85801 & $\begin{array}{l}\text { Forward: GCCGTGACTGTGCCATGA } \\
\text { Reverse: GTGTTGATCCAGGGCAGGAA }\end{array}$ & $300 / 300$ \\
\hline UPAR & S70635 & $\begin{array}{l}\text { Forward: GCCGCGGCCCTATGA } \\
\text { Reverse: GCTTGGGTTCCTCAGTCCTTT }\end{array}$ & $300 / 300$ \\
\hline PAI-1 & X16383 & $\begin{array}{l}\text { Forward: TGGGCCCGTGGAACAA } \\
\text { Reverse: AGGTCCCGCTGCACGAA }\end{array}$ & $300 / 300$ \\
\hline PAI-2 & AF416234 & $\begin{array}{l}\text { Forward: CCATATGCTGGCGATGTCAGT } \\
\text { Reverse: GCCCGTAGAGGATTCAGCAA }\end{array}$ & $300 / 300$ \\
\hline RPL-19 & XM_587778 & $\begin{array}{l}\text { Forward: CAGACGATACCGTGAATCTAAGAAGA } \\
\text { Reverse: TGAGAATCCGCTTGTTTTTGAA }\end{array}$ & $300 / 300$ \\
\hline
\end{tabular}

* Forward/reverse primer ratio was determined by primer matrix analysis.

\section{Protein extraction}

Homogenates of follicle apex and base were prepared as described previously (Bakke et al. 2002). Briefly, the apical or basal portions of each follicle were homogenized in $300 \mu \mathrm{l}$ homogenization buffer $(10 \mathrm{mM}$ calcium chloride and $0.25 \%$ Triton X-100). The homogenates were then centrifuged at $9000 \mathrm{~g}$ for $30 \mathrm{~min}$ at $4{ }^{\circ} \mathrm{C}$. The supernatants were collected, and protein concentration was determined by Lowry's method (Lowry et al. 1951). Aliquots of proteins were frozen at $-20^{\circ} \mathrm{C}$ until analyzed.

\section{Immunoblot analysis}

Immunoblot analysis was conducted for quantification of TIMP-4 protein by our previously described protocol (Li et al. 2004). Membranes were stripped and reprobed with the actin antibody for normalization and quantification (Li et al. 2004). Rabbit antihuman TIMP-4 polyclonal antibody and mouse antihuman actin monoclonal antibody were obtained from Chemicon (Temecula, CA, USA), while donkey antirabbit and goat antimouse antibodies were purchased from Amersham Biosciences (Bucks, UK) and GenoTech (St Louis, MO, USA) respectively.

\section{Casein zymography}

The activity of IPA, UPA, and plasmin in the follicle apex, base and FF was measured by casein zymography, as described previously (Dow et al. 2002a). A homogenate of bovine cerebellum served as a positive control for tPA activity and bovine ovarian surface epithelial cell-conditioned medium as a positive control for uPA activity (Dow et al. 2002a).

\section{Statistical analysis}

Differences in $\mathrm{PGE}_{2}$ concentration, mRNA abundance, protein amounts and enzymatic activities among different time points/groups were determined by one-way analysis of variance (ANOVA) with the general linear model procedure of the Statistical Analysis System (Version 8, SAS Institute, Cary, NC, USA). When heterogeneity of variance was observed, data were log transformed before statistical analysis. Individual comparisons were performed with Tukey's test. Data are reported as least-square (LS) mean \pm pooled S.E.M. $P<0.05$ was considered statistically significant.

\section{Results}

\section{Reduced FF $\mathrm{PGE}_{2}$ after intrafollicular INDO injection}

FF $\mathrm{PGE}_{2}$ concentrations were low in 0-h preovulatory follicle samples collected before $\mathrm{GnRH}$ injection, but were markedly increased at $24 \mathrm{~h}$ after $\mathrm{GnRH}$ administration $(P<0.01)$ (Fig. 1). A dose of $200 \mu \mathrm{g} / \mathrm{ml}$ INDO was selected for intrafollicular injection, on the basis of the results of a preliminary dose-response experiment 


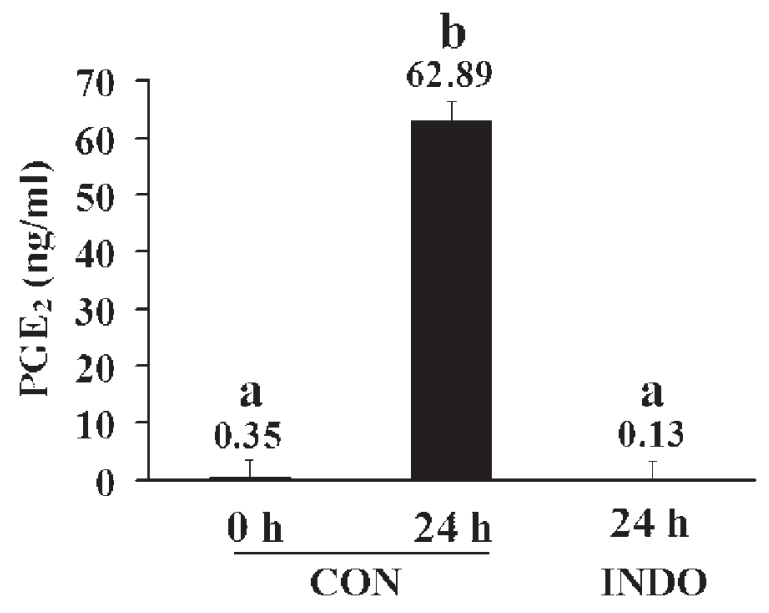

Figure 1 Effect of intrafollicular indomethacin (INDO) injection on concentrations of follicular fluid $\mathrm{PGE}_{2}$ in preovulatory follicles collected at $0 \mathrm{~h}(\mathrm{CON}), 24 \mathrm{~h}(\mathrm{CON})$ and $24 \mathrm{~h}(\mathrm{INDO})$ relative to $\mathrm{GnRH}$ injection ( $n=5$ each). Each bar represents the least-square (LS) mean \pm pooled S.E.M. Bars without a common superscript are different at $P<0.01$. CON: control; diluent-treated follicles; INDO: indomethacin-treated follicles.

(diluent control $=72 \mathrm{ng} / \mathrm{ml} \mathrm{PGE}_{2} ; 200 \mu \mathrm{g} / \mathrm{ml}$ INDO $=130$ $\mathrm{pg} / \mathrm{ml} \mathrm{PGE} ; 1000 \mu \mathrm{g} / \mathrm{ml} \mathrm{INDO}=40 \mathrm{pg} / \mathrm{ml} \mathrm{PGE}_{2}$ ) comparing the ability of two doses of INDO to suppress the gonadotropin surge-induced increase in $\mathrm{FF} \mathrm{PGE}_{2}$ (measured as an index of intrafollicular prostanoid synthesis) at $24 \mathrm{~h}$ after GnRH injection. Intrafollicular injection of INDO blocked the gonadotropin surge-induced increase in FF $\mathrm{PGE}_{2}$ at $24 \mathrm{~h}$ after $\mathrm{GnRH}$ injection $(P<0.01)$ (Fig. 1), resulting in concentrations similar to those observed at the 0-h time point.

\section{Changes in MMP and PA system component mRNAs in specific follicular cell compartments (GC and TC) after the preovulatory gonadotropin surge}

Because the intrafollicular cell types responsible for increases in select MMP and PA system components in bovine preovulatory follicles are not known, we examined the effect of the preovulatory gonadotropin surge on mRNA abundance for select MMP and PA and their inhibitors specifically within GC and TC. MMP-13 transcripts were mainly detected in TC, while mRNAs for TIMP-2, tPA and PAI-2 were mainly in GC. Messenger RNAs for MMP-14, MMP-28, TIMP-1, TIMP-3, TIMP-4, UPA, UPAR and PAI-1 were detected in both GC and TC. In the GC compartment, TIMP-3, tPA, UPA, uPAR and PAI-1 mRNAs were increased at both 12 and $24 \mathrm{~h}$ after $\mathrm{GnRH}$ injection $(P<0.05)$ (Fig. $2 \mathrm{~F}$ and $\mathrm{H}-\mathrm{K}$ ). In contrast, elevated transcript abundance for MMP-14, TIMP-1, TIMP-2 and TIMP4 was observed only at $12 \mathrm{~h}(P<0.05)$ (Fig. $2 \mathrm{~B}, \mathrm{D}, \mathrm{E}$ and G); Abundance of GC MMP-28 and PAI-2 mRNAs was increased only at $24 \mathrm{~h}(P<0.05)$ (Fig. $2 \mathrm{C}$ and $\mathrm{L})$. In the TC compartment, MMP-13, uPA, UPAR and PAI-1 mRNAs were elevated at both time points examined $(P<0.05)$
(Fig. 2A and I-K). TIMP-1 and TIMP-4 mRNAs in TC were upregulated only at $12 \mathrm{~h}(P<0.05)$ (Fig. $2 \mathrm{D}$ and $\mathrm{G})$, while a significant increase in TC mRNA abundance for MMP14 was detected only at $24 \mathrm{~h}$ after $\mathrm{GnRH}$ injection $(P<0.05)$ (Fig. 2B). No changes in MMP-28 and TIMP-3 mRNAs in TC were observed after $\mathrm{GnRH}$ injection $(P>0.05)$ (Fig. 2C and F).

\section{Effect of intrafollicular administration of INDO on GC and TC MMP and PA system component mRNA abundance}

Among the seven MMPs and TIMPs examined (MMP-13, MMP-14, MMP-28 and TIMPs 1-4), only abundance of TIMP-4 transcripts was increased in TC of INDO-treated animals $(P<0.05)$ (Fig. 3A). Effects of INDO on mRNA abundance for other MMPs and TIMPs were not detected (data not shown). For the PA system components, intrafollicular administration of INDO significantly decreased tPA, PAI- 1 and PAI-2 mRNA abundance in GC $(P<0.05)$ (Fig. 3B, E and F) and UPA, UPAR and PAI-1 $(P<0.05)$ (Fig. 3C-E) mRNA abundance in TC.

\section{Effect of intrafollicular administration of INDO on amount of TIMP-4 protein in the follicle apex and base}

Immunoblot analysis was utilized to determine whether changes in abundance of TIMP-4 protein mirror changes in mRNA abundance observed in INDO-treated follicles and whether regulation was specific to the follicular apex. The TIMP-4 antibody recognized a single band of $28000 \mathrm{Da}$ in bovine preovulatory follicles. Amounts of TIMP-4 protein were increased in the apex $(P<0.05)$ (Fig. 4), but not the base (data not shown), in INDO-treated versus control follicles.

\section{Effect of intrafollicular INDO injection on follicular tPA, uPA and plasmin activity}

Activities for both tPA (single band) and UPA (double bands; presumably corresponding to the single- and twochain forms of UPA) were detected in the follicle apex and base (Fig. 5A, lanes 1 and 4). Plasmin and tPA activity was detected in FF (Fig. 5A, lane 5). Very minor activity for plasmin in follicle homogenates and UPA in FF was observed (data not shown). Activity for tPA, UPA and plasmin was not observed when plasminogen was omitted from gels (data not shown). Incubation of gels in the presence of amiloride, a specific uPA inhibitor, dramatically attenuated activity corresponding to uPA (Fig. 5A, lane 2), and incubation with aprotinin, the plasmin inhibitor, attenuated both PA activity in follicle homogenates (Fig. 5A, lane 3 ) and plasmin activity in FF (data not shown). In the follicle apex, tPA activity was significantly decreased in response to INDO treatment $(P<0.05)$ (Fig. 5B). In the follicle base, neither tPA nor UPA activities were significantly affected by INDO treatment (data not 


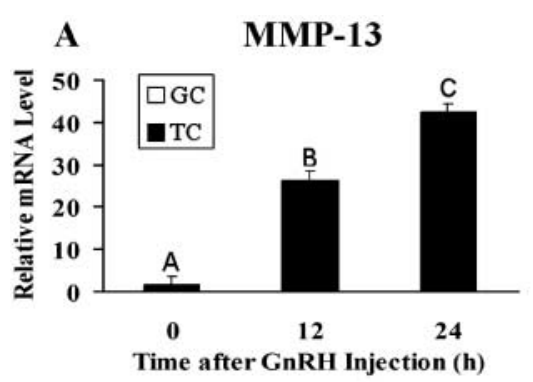

B MMP-14

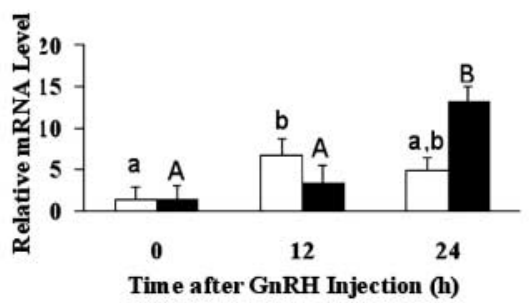

E

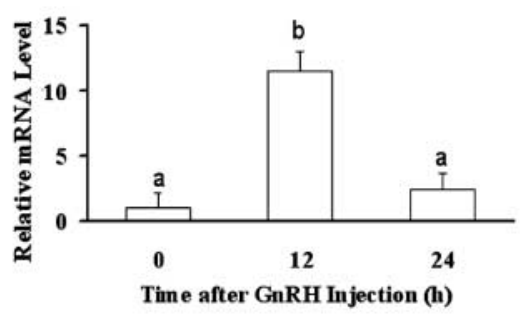

H

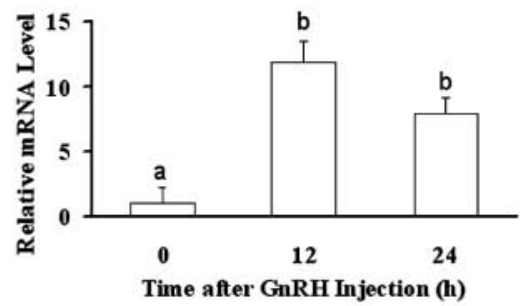

K

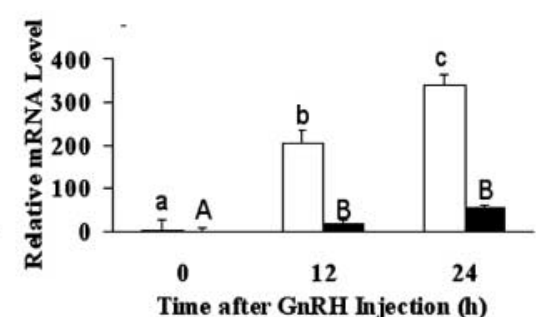

C

MMP-28

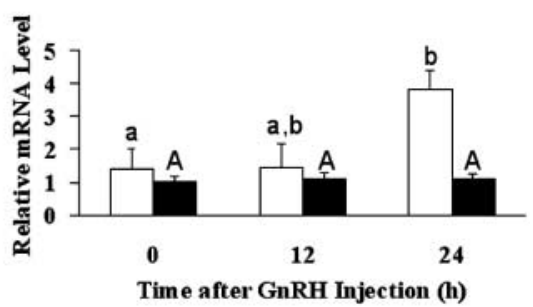

F TIMP-3

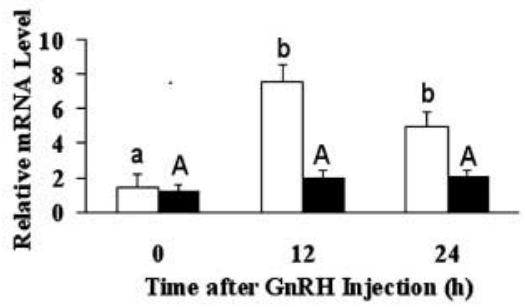

I UPA

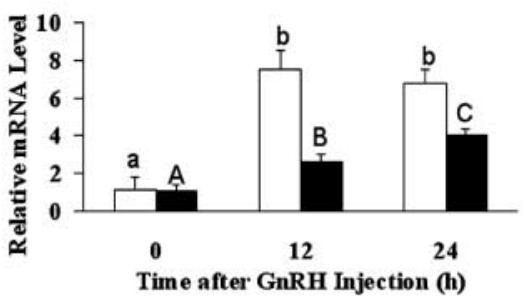

L

PAI-2

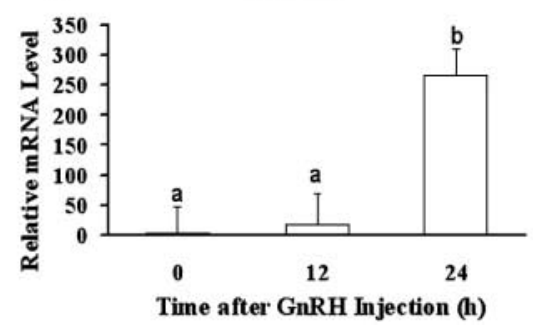

Figure 2 Real-time PCR analysis of changes in MMP and PA system component mRNA abundance in GC and/or TC of bovine preovulatory follicles after the gonadotropin surge. Abundance of MMP-13 (A), MMP-14 (B), MMP-28 (C), TIMP-1 (D), TIMP-2 (E), TIMP-3 (F), TIMP-4 (G), tPA $(\mathrm{H}), \mathrm{uPA}(\mathrm{I})$, uPAR (J), PAI-1 (K) and PAI-2 (L) mRNAs was normalized relative to that of RPL-19 mRNA. Relative mRNA abundance at $0 \mathrm{~h}$ $(n=5), 12 \mathrm{~h}(n=3)$ and $24 \mathrm{~h}(n=5)$ relative to $\mathrm{GnRH}$ injection was calculated by the $\Delta \Delta \mathrm{CT}$ method. Data are shown as least-square (LS) mean \pm pooled S.E.M. Time points without a common superscript (lower case for GC and upper case for TC) are different at $P<0.05$.

GC: granulosal cell; TC: thecal tissue.

shown). In FF, plasmin and tPA activity were both reduced in INDO-treated follicles versus control follicles $(P<0.05)$ (Fig. 5C).

\section{Discussion}

Despite the well-established role of prostanoids in ovulation, the downstream targets via which prostanoids help promote the ovulatory process remain to be completely illustrated. The present studies tested the hypothesis that the gonadotropin surge-induced regulation of select ECMdegrading enzymes and their inhibitors potentially involved in ovulation is blocked by local administration of the prostanoid synthesis and ovulation inhibitor INDO. We showed for the first time that intrafollicular INDO injection in vivo resulted in increased TC mRNA 

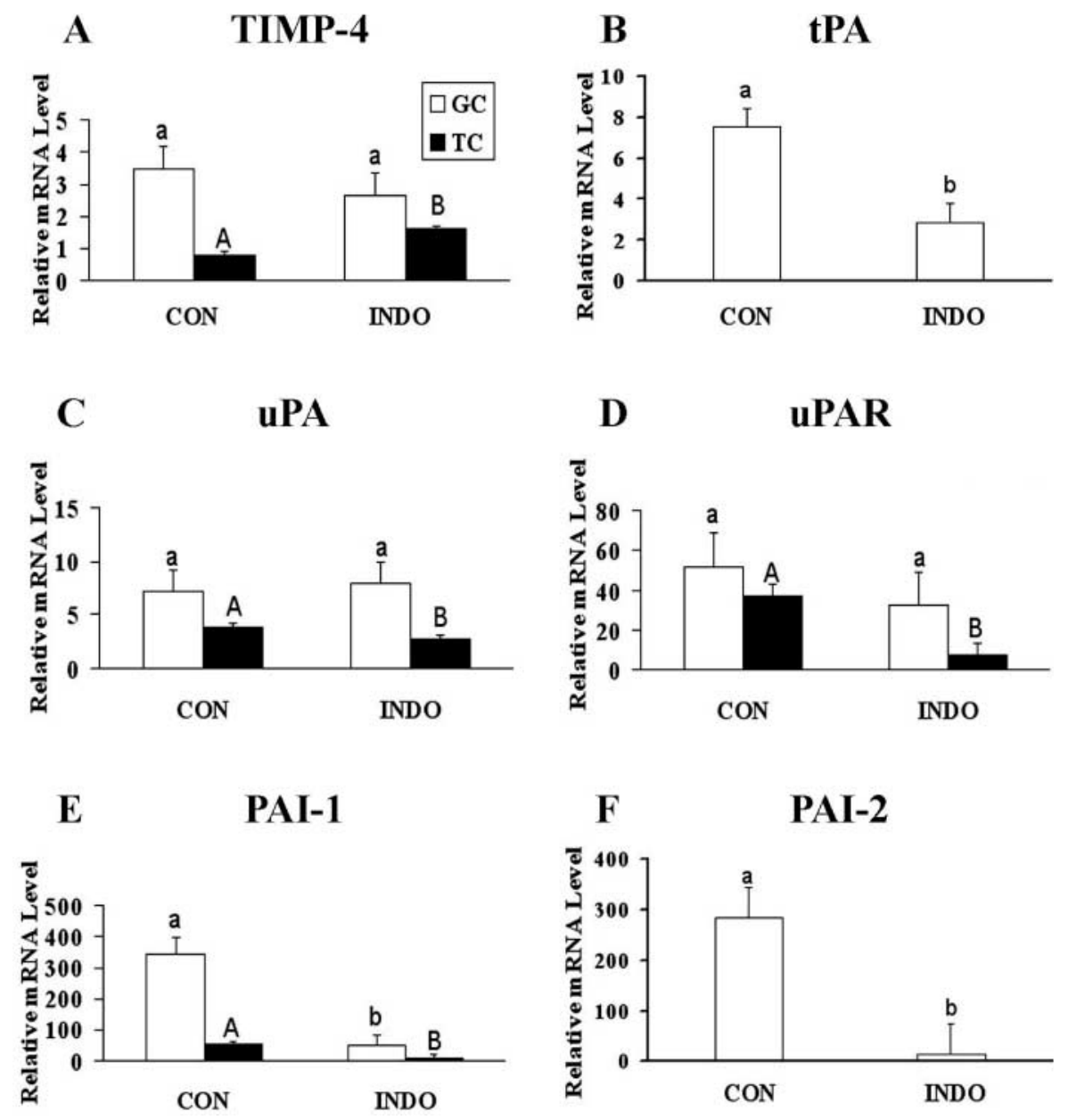

Figure 3 Real-time PCR analysis of the
effect of INDO injection on MMP and
PA system component mRNA abundance
in GC and/or TC of bovine preovulatory
follicles. Abundance of TIMP-4 (A),
tPA (B), uPA (C), uPAR (D), PAI-1 (E) and
PAI-2 (F) mRNAs was normalized relative
to that of RPL-19 mRNA. Relative mRNA
abundance at $24 \mathrm{~h}$ after GnRH injection
for the CON ( $n=5$ ) and INDO-treated
groups ( $n=5$ ) was calculated by the
$\Delta \Delta$ CT method. Data are shown as least-
square (LS) mean \pm pooled s.E.M. Bars
without a common superscript (lower
case for GC and upper case for TC) are
different at $P<0.05$. CON: control;
diluent-treated follicles; INDO: INDO-
treated follicles; GC: granulosal cell;
TC: thecal tissue.

abundance for TIMP-4 and increased TIMP-4 protein in the apex of bovine preovulatory follicles before ovulation, and suppressed GC mRNA and activity for tPA in FF and the follicle apex, and plasmin activity in FF. Given the key role of prostanoids in the ovulatory process (Murdoch et al. 1986, Dinchuk et al. 1995, Lim et al. 1997, Mikuni et al. 1998, Peters et al. 2004), results from the current study support a potential functional role for prostanoidmediated suppression of TIMP-4 and maintenance of elevated tPA expression in the mechanism of ovulation.

We acknowledge that we cannot exclusively attribute the effects of INDO administration on expression of TIMP4 and tPA specifically to absence of a specific prostanoid and/or to inhibition of COX-2 activity. Prostanoids are synthesized from arachidonic acid by the action of COX-1 and 2, and COX inhibitors, including INDO, inhibit ovulation both in vivo and in vitro (De Silva \& Reeves 1985, Mikuni et al. 1998, Gaytan et al. 2002, Peters et al. 2004). Measurement of $\mathrm{PGE}_{2}$ was used as an index of intrafollicular prostanoid synthesis in the present studies. Although FF concentrations of $\mathrm{PGE}_{2}$ and $\mathrm{PGF}_{2 \alpha}$ both increase after the LH surge in cattle (Sirois 1994), the time course of induction of the $\mathrm{PGF}_{2 \alpha}$ receptor (FP receptor) is not consistent with a role in bovine ovulation (Tsai et al. 1996).

Thus, $\mathrm{PGF}_{2 \alpha}$ regulation of TIMP-4 and tPA seems unlikely, despite evidence of $\mathrm{PGF}_{2 \alpha}$ regulation of MMP expression in other systems (Weinreb et al. 2004). Furthermore, a predominant contribution of COX-1 inhibition to the suppression of $\mathrm{PGE}_{2}$ observed in the present study seems unlikely. COX-1 immunoreactivity is low or undetectable in bovine preovulatory follicles (Sirois 1994), and FF concentrations of $\mathrm{PGE}_{2}$ in INDO-treated follicles were not different from the pre-gonadotropin surge concentrations of $\mathrm{PGE}_{2}$ observed at the 0 -h time point.

The current study was built on our previous identification of select MMP and PA system components that are increased in bovine preovulatory follicles after the gonadotropin surge and thus are potential regulators of ovulation. Increased expression of select MMP and PA system components in bovine preovulatory follicles after the $\mathrm{LH}$ surge was observed in our previous studies (Smith et al. 1996, Bakke et al. 2002, 2004, Dow et al. 2002a,b, Li et al. 2004), primarily using RNA isolated from whole follicles. Cellular localization of expression was determined by qualitative in situ hybridization or immunohistochemistry procedures. However, previous studies did not directly quantify the gonadotropin surge-induced regulation of mRNA for select MMP and PA system components 


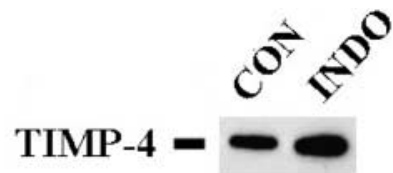

Actin $=-\infty$

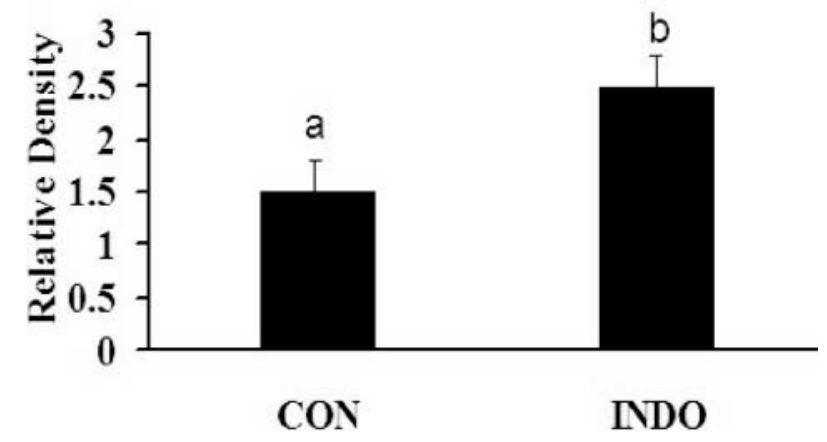

Figure 4 Effect of intrafollicular INDO injection on TIMP-4 protein abundance in homogenates of the apex of bovine preovulatory follicles. Upper panel: representative immunoblots demonstrating a single band of immunoreactivity for TIMP-4 (28000 Da) in homogenates of follicle apex collected $24 \mathrm{~h}$ after GnRH injection. Lower panel: relative mean abundance of TIMP-4 protein derived from analysis of individual samples of homogenates of the follicle apex of INDO-treated versus control follicles ( $n=5$ per time point). Data are shown as least-square (LS) mean \pm pooled S.E.M. Bars without a common superscript are different at $P<0.05$. CON: control; diluenttreated follicles; INDO: indomethacin-treated follicles.

specifically in the two steroidogenic cell populations of preovulatory follicles that can respond both directly and indirectly to the LH surge. Thus, real-time PCR analysis was utilized in the present studies to examine regulation of MMP and PA system component mRNA abundance specifically in the GC and TC. As a whole, cellular source and the observed temporal changes in mRNA expression in GC and TC agree with previously published data for whole follicles with only a few exceptions (such as increased MMP-13 and PAl-1 mRNAs $12 \mathrm{~h}$ after GnRH injection and predominant localization of PAI- 1 to the thecal layer). Such discrepancies are not easily explained, but they are probably attributable to the more sensitive and quantitative nature of the real-time PCR procedure used here than that of the dot-blot (Dow et al. 2002b) and semiquantitative RT-PCR procedures (Bakke et al. 2004) used previously, to differences in the nature of samples collected (whole follicles versus isolated GC and TC in present studies), to differences in the experimental model used in previous studies (Smith et al. 1996, Li et al. 2004) and degree of follicle synchrony at time of induction of the LH surge, and to the qualitative nature of procedures used previously for determination of cellular localization of mRNA and relative abundance in GC versus TC (Dow et al. 2002b).

Among the seven MMPs and TIMPs examined here (MMP-13, MMP-14, MMP-28 and TIMPs 1-4), only mRNA for TIMP-4 changed significantly in response to INDO treatment. The results of our previous study (Li et al. 2004) demonstrated that the gonadotropin surge-induced increase in TIMP-4 mRNA and protein abundance is transient and maximal at $12 \mathrm{~h}$ after $\mathrm{GnRH}$ injection. We further demonstrated here that abundance of TC TIMP-4 mRNA and amounts of TIMP-4 protein in the follicular apex, but not the base, were increased in response to INDO treatment of preovulatory follicles, suggesting a potential key role for intrafollicular prostanoids in downregulation of TIMP-4 expression during the window of time immediately before ovulation. Prostanoid-dependent regulation of MMP-14 and MMP-28 has not been reported. Furthermore, the effects of INDO administration on gonadotropin surge-induced expression of mRNA for TIMP family members in the present studies were specific to TIMP-4. An effect of INDO administration on TIMP-1 mRNA in rat ovaries was not observed in previous studies (Curry et al. 2000), but an inhibitory effect of $\mathrm{PGF}_{2 \alpha}$ on LH-stimulated TIMP-1 mRNA expression in macaque GC in vitro has been documented (Duffy \& Stouffer 2003). To date, the effects of INDO administration on ovarian TIMP2, TIMP-3 and TIMP-4 mRNA during the ovulatory process have not been reported in other species.

Unlike TIMPs 1-3, the TIMP-4 promoter region has no AP-1 motif, but contains consensus motifs for Sp1 and an inverted CCAAT box upstream of an initiator-like element that is in close proximity to a transcription start site, both of which have functional importance in TIMP-4 gene expression (Young et al. 2002). These unique features of the TIMP-4 promoter might have implications for selective TIMP-4 regulation by prostanoids, but the factors that bind specifically to the TIMP-4 initiator-like element and functional complexes that bind the putative CCAAT and Sp1 motifs are not known (Young et al. 2002).

Although coordinate upregulation of both MMPs and TIMPs is common during ECM remodeling (Curry \& Osteen 2003), the balance is tipped in favor of MMP activity before ovulation (Curry \& Osteen 2003). To our knowledge, the effects of intrafollicular INDO injection in vivo on preovulatory ovarian/follicular MMP inhibitor activity have not been reported. We propose that a potential key role for prostanoids in the mechanism of ovulation is to promote downregulation of gonadotropin surgeinduced TIMP-4 expression in the follicular apex, in order to shift the MMP/TIMP ratio in favor of MMPs and help regulate, temporally and spatially, ovarian ECM degradation and follicle rupture. Unlike data reported in rodents (Simpson et al. 2003), TIMP-4 mRNA and protein are readily detectable in bovine preovulatory follicles, and TIMP-4 mRNA appears to be of similar abundance as mRNAs for TIMP 1-3 (Li et al., unpublished). However, the relative abundance of TIMP-4 protein relative to the other TIMPs and hence the contribution of TIMP-4 to total MMP inhibitor activity in bovine preovulatory follicles remain to be determined. 
Follicle Apex
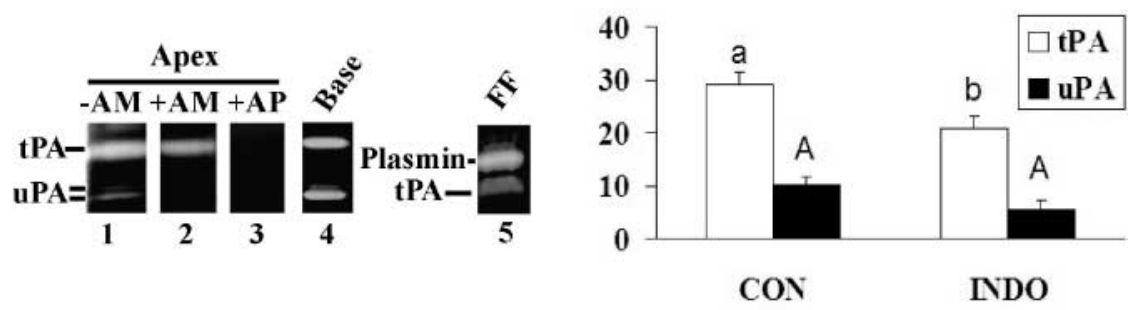

C

Follicular Fluid

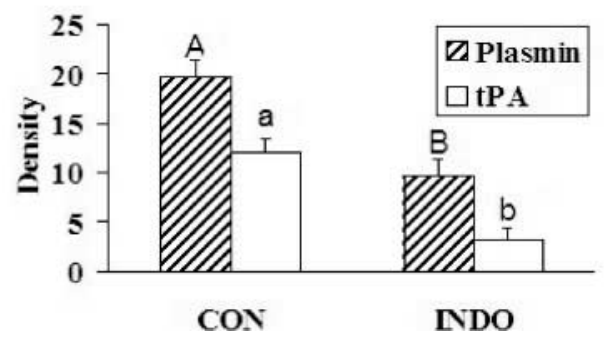

Figure 5 Casein zymographic analysis of the effect of intrafollicular INDO injection on TPA, uPA and plasmin activity in the apex, base and follicular fluid (FF) of bovine preovulatory follicles collected $24 \mathrm{~h}$ after $\mathrm{GnRH}$ injection. (A) Representative pictures depict the bands of activity for tPA, UPA and plasmin in follicular apex (lane 1), base (lane 4) and FF (lane 5). Specificity of IPA and uPA activity was confirmed by incubating the gels in the absence or presence of amiloride (uPA specific inhibitor; $1 \mathrm{mM} ; \pm \mathrm{AM}$; lanes 1 and 2 ) or $2 \mu \mathrm{g} / \mathrm{ml}$ of the plasmin inhibitor aprotinin (+AP; lane 3). Effects of INDO injection on the activity of tPA, uPA and/or plasmin in follicle apex (B) and FF (C) were analyzed by densitometry ( $n=5$ per time point). Data are shown as least-square (LS) mean \pm pooled S.E.M. Bars without a common superscript (panel B: lower case for tPA and upper case for UPA; panel C: upper case for plasmin and lower case for tPA) are different at $P<0.05$. CON: control; diluent-treated follicles; INDO: indomethacin-treated follicles.

In contrast to MMP system components analyzed, where effects of INDO administration were limited, mRNAs for all the PA system components examined were decreased in GC and/or TC compartments of INDOinjected follicles. Messenger RNA abundance for tPA in GC was decreased. Interestingly, we previously reported differential regulation of tPA activity in the follicle apex versus the base (Dow et al. 2002a). Activity for tPA was increased in the follicle apex but remained unchanged in the base $24 \mathrm{~h}$ after GnRH injection (Dow et al. 2002a). Therefore, it seems that the gonadotropin surge-induced regulation of preovulatory tPA activity is specific to the follicle apex. In the current study, we further demonstrated that IPA activity in the follicle apex, but not the base, was attenuated by INDO injection, and both tPA and plasmin activities in FF were decreased in INDO-treated follicles. The mechanisms responsible for differential effects of INDO administration on tPA activity in the apex versus the base of bovine preovulatory follicles are unclear.

As stated above, given the temporal changes in tPA mRNA and activity previously observed in response to the gonadotropin surge in samples collected before the 24-h time point (Dow et al. 2002a), the results of the present studies support a potential role for intrafollicular prostanoids in maintenance of the gonadotropin surge-induced increase in TPA mRNA and activity and FF plasmin activity in bovine preovulatory follicles immediately before ovulation. Our data agree with previous studies from other systems that demonstrated a role for prostanoids in stimulating tPA mRNA and generation of plasmin activity by glomerular mesangial cells (Coffman et al. 1998). Moreover, $\mathrm{PGE}_{1}$ and $\mathrm{PGE}_{2}$ stimulated rat $\mathrm{GC}$ to produce PA in vitro (Strickland \& Beers 1976), the predominant enzyme of which migrates with an apparent molecular mass of 75000 Da (Strickland \& Beers 1976), presumably corresponding to tPA.

Another interesting observation derived from the present studies was the selective effects of INDO on mRNA for MMP and PA system components within the two follicular cell compartments (GC and TC) of bovine preovulatory follicles. For example, TIMP-4 mRNA expression in TC, but not GC, was affected by INDO administration, yet GC expression of tPA mRNA was influenced by INDO administration. Due to the lack of knowledge of prostanoid signaling pathways activated during ovulation, and lack of information on prostanoid receptor subtype expression patterns in different follicular cell compartments (TC and GC) during the preovulatory period, we cannot determine from the present studies whether both TC and GC of bovine preovulatory follicles can respond to prostanoids directly, or whether the differential regulation observed is attributable to direct versus indirect effects of prostanoids and/or differential sensitivity of various PG-responsive genes to the signal transduction pathways involved. Furthermore, although the best-established function of INDO is to inhibit COX activity, other roles independent of prostanoid inhibition, including induction of $\mathrm{Hsc70}$ nuclear 
translocation (Lagunas et al. 2004) and activation of PPAR $\gamma$ (Tegeder et al. 2001), have been demonstrated.

In summary, we have determined the effect of intrafollicular INDO administration on LH surge-induced regulation of select ECM degrading enzymes and their cognate inhibitors previously implicated in the ovulatory process. The present studies clearly demonstrated that gonadotropin surge-induced regulation of TIMP-4 and tPA mRNAs, TIMP-4 protein and TPA activity in the follicle apex, and FF tPA and plasmin activity is blocked by intrafollicular INDO administration in cattle. Collectively, the results illustrate a potential obligatory prostanoid-dependent mechanism for regulation of ovulation in cattle, but further investigation will be required to establish directly an essential role for these mediators of ECM remodeling in the ovulatory process.

\section{Acknowledgements}

We thank Dr Osman Patel, Anilkumar Bettegowda, Larry Chapin, Heather Dover, Dr Monika Mihm, Nora Bello, Crystal Huston, Tracey Pierzchala and Katie Pierson for their excellent assistance with animal handling and tissue collection and preparation, and Larry Chapin for his assistance with statistical analysis. This project was supported by National Research Initiative Competitive Grant no. 2003-35203-12841 from the USDA Cooperative State Research, Education, and Extension Service (GWS) and the Michigan Agricultural Experiment Station. The authors declare that there is no conflict of interest that would prejudice the impartiality of this scientific work.

\section{References}

Alexander CM \& Werb Z 1991 Extracellular matrix degradation. In Cell Biology of the Extracellular Matrix, 2nd edn, pp 255-302. Ed ED Hay. New York: Plenum.

Bakke LJ, Dow MP, Cassar CA, Peters MW, Pursley JR \& Smith GW 2002 Effect of the preovulatory gonadotropin surge on matrix metalloproteinase (MMP)-14, MMP-2, and tissue inhibitor of metalloproteinases-2 expression within bovine periovulatory follicular and luteal tissue. Biology of Reproduction 66 1627-1634.

Bakke LJ, Li Q, Cassar CA, Dow MP, Pursley JR \& Smith GW 2004 Gonadotropin surge-induced differential upregulation of interstitial collagenase (MMP-1) and collagenase-3 (MMP-13) mRNA and protein in bovine preovulatory follicles. Biology of Reproduction 71 605-612.

Brew K, Dinakarpandian D \& Nagase H 2000 Tissue inhibitors of metalloproteinases: evolution, structure and function. Biochimica et Biophysica Acta 1477 267-283.

Coffman TM, Spurney RF, Mannon RB \& Levenson R 1998 Thromboxane A2 modulates the fibrinolytic system in glomerular mesangial cells. American Journal of Physiology 275 F262-F269.

Curry TE Jr \& Osteen KG 2003 The matrix metalloproteinase system: changes, regulation, and impact throughout the ovarian and uterine reproductive cycle. Endocrine Reviews 24 428-465.

Curry TE Jr, Komar CM, Burns PD \& Nothnick WB 2000 Preovulatory changes in ovarian metalloproteinases and tissue inhibitors of metalloproteinases (TIMPs) following indomethacin treatment. In Ovulation: Evolving Scientific and Clinical Concepts, pp 265-276. Ed EY Adashi. New York: Springer Verlag.

Davis BJ, Lennard DE, Lee CA, Tiano HF, Morham SG, Wetsel WC \& Langenbach R 1999 Anovulation in cyclooxygenase-2-deficient mice is restored by prostaglandin $\mathrm{E}_{2}$ and interleukin-1beta. Endocrinology $1402685-2695$.

De Silva M \& Reeves JJ 1985 Indomethacin inhibition of ovulation in the cow. Journal of Reproduction and Fertility 75 547-549.

DeClerck YA \& Laug WE 1996 Cooperation between matrix metalloproteinases and the plasminogen activator-plasmin system in tumor progression. Enzyme and Protein 49 72-84.

Dinchuk JE, Car BD, Focht RJ, Johnston JJ, Jaffee BD, Covington MB, Contel NR, Eng VM, Collins RJ, Czerniak PM et al. 1995 Renal abnormalities and an altered inflammatory response in mice lacking cyclooxygenase II. Nature 378 406-409.

Dow MP, Bakke LJ, Cassar CA, Peters MW, Pursley JR \& Smith GW 2002a Gonadotropin surge-induced up-regulation of the plasminogen activators (tissue plasminogen activator and urokinase plasminogen activator) and the urokinase plasminogen activator receptor within bovine periovulatory follicular and luteal tissue. Biology of Reproduction 66 1413-1421.

Dow MP, Bakke LJ, Cassar CA, Peters MW, Pursley JR \& Smith GW $2002 b$ Gonadotropin surge-induced upregulation of mRNA for plasminogen activator inhibitors 1 and 2 within bovine periovulatory follicular and luteal tissue. Reproduction 123 711-719.

Drost M, Savio JD, Barros CM, Badinga L \& Thatcher WW 1992 Ovariectomy by colpotomy in cows. Journal of the American Veterinary Medical Association 200 337-339.

Duffy DM \& Stouffer RL 2003 Luteinizing hormone acts directly at granulosa cells to stimulate periovulatory processes: modulation of luteinizing hormone effects by prostaglandins. Endocrine 22 249-256.

Gaytan F, Tarradas E, Bellido C, Morales C \& Sanchez-Criado JE 2002 Prostaglandin E1 inhibits abnormal follicle rupture and restores ovulation in indomethacin-treated rats. Biology of Reproduction 67 1140-1147.

Gomez DE, Alonso DF, Yoshiji H \& Thorgeirsson UP 1997 Tissue inhibitors of metalloproteinases: structure, regulation and biological functions. European Journal of Cell Biology 74 111-122.

Ito $H$, Duxbury M, Benoit E, Clancy TE, Zinner MJ, Ashley SW \& Whang EE 2004a Prostaglandin $E_{2}$ enhances pancreatic cancer invasiveness through an Ets-1-dependent induction of matrix metalloproteinase-2. Cancer Research 64 7439-7446.

Ito $\mathbf{H}$, Duxbury M, Benoit E, Farivar RS, Gardner-Thorpe J, Zinner MJ, Ashley SW \& Whang EE 2004b Fibronectin-induced COX-2 mediates MMP-2 expression and invasiveness of rhabdomyosarcoma. Biochemical and Biophysical Research Communications 318 594-600.

Lagunas L, Bradbury CM, Laszlo A, Hunt CR \& Gius D 2004 Indomethacin and ibuprofen induce Hsc70 nuclear localization and activation of the heat shock response in HeLa cells. Biochemical and Biophysical Research Communications 313 863-870.

Li Q, Bakke LJ, Pursley JR \& Smith GW 2004 Localization and temporal regulation of tissue inhibitors of metalloproteinases 3 and 4 in bovine preovulatory follicles. Reproduction 128 555-564.

Li QL, Illman SA, Wang HM, Liu DL, Lohi J \& Zhu C 2003 Matrix metalloproteinase-28 transcript and protein are expressed in rhesus monkey placenta during early pregnancy. Molecular Human Reproduction 9 205-211.

Lim H, Paria BC, Das SK, Dinchuk JE, Langenbach R, Trzaskos JM \& Dey SK 1997 Multiple female reproductive failures in cyclooxygenase 2-deficient mice. Cell 91 197-208.

Liu CM, Hong CY, Shun CT, Wang JS, Hsiao TY, Wang CC \& Lin SK 2001 Matrix metalloproteinase-1 and tissue inhibitor of metalloproteinase- 1 gene expressions and their differential regulation by proinflammatory cytokines and prostaglandin in nasal polyp fibroblasts. Annals of Otology, Rhinology, and Laryngology $\mathbf{1 1 0}$ 1129-1136.

Livak KJ \& Schmittgen TD 2001 Analysis of relative gene expression data using real-time quantitative PCR and the 2(-delta delta C(T)) method. Methods 25 402-408.

Lohi J, Wilson CL, Roby JD \& Parks WC 2001 Epilysin, a novel human matrix metalloproteinase (MMP-28) expressed in testis and 
keratinocytes and in response to injury. Journal of Biological Chemistry 276 10134-10144.

Lowry OH, Rosebrough NJ, Farr AL \& Randall RJ 1951 Protein measurement with the Folin phenol reagent. Journal of Biological Chemistry 193 265-275.

Marchenko GN \& Strongin AY 2001 MMP-28, a new human matrix metalloproteinase with an unusual cysteine-switch sequence, is widely expressed in tumors. Gene 265 87-93.

Mignatti P, Robbins E \& Rifkin DB 1986 Tumor invasion through the human amniotic membrane: requirement for a proteinase cascade. Cell 47 487-498.

Mikuni $M$, Pall $M$, Peterson CM, Peterson CA, Hellberg $\mathbf{P}$ Brannstrom M, Richards JS \& Hedin L 1998 The selective prostaglandin endoperoxide synthase-2 inhibitor, NS-398, reduces prostaglandin production and ovulation in vivo and in vitro in the rat. Biology of Reproduction 59 1077-1083.

Miyaura C, Inada M, Suzawa T, Sugimoto Y, Ushikubi F, Ichikawa A, Narumiya S \& Suda T 2000 Impaired bone resorption to prostaglandin $E_{2}$ in prostaglandin E receptor EP4-knockout mice. Journal of Biological Chemistry 275 19819-19823.

Murdoch WJ \& McCormick RJ 1992 Enhanced degradation of collagen within apical vs. basal wall of ovulatory ovine follicle. American Journal of Physiology 263 E221-E225.

Murdoch WJ \& Gottsch ML 2003 Proteolytic mechanisms in the ovulatory folliculo-luteal transformation. Connective Tissue Research 44 50-57.

Murdoch WJ, Peterson TA, Van Kirk EA, Vincent DL \& Inskeep EK 1986 Interactive roles of progesterone, prostaglandins, and collagenase in the ovulatory mechanism of the ewe. Biology of Reproduction 35 1187-1194.

Murphy G, Stanton H, Cowell S, Butler G, Knauper V, Atkinson S \& Gavrilovic J 1999 Mechanisms for pro matrix metalloproteinase activation. Acta Pathologica, Microbiologica et Immunologica Scandinavica 107 38-44.

Nagase H \& Woessner JF Jr 1999 Matrix metalloproteinases. Journal of Biological Chemistry $27421491-21494$.

Negoro H, Soo Shin W, Hakamada-Taguchi R, Eguchi N, Urade $\mathrm{Y}$, Goto A, Toyo-Oka T, Fujita T, Omata M \& Uehara Y 2002 Endogenous prostaglandin $D_{2}$ synthesis reduces an increase in plasminogen activator inhibitor-1 following interleukin stimulation in bovine endothelial cells. Journal of Hypertension 20 $1347-1354$

Ny T, Wahlberg P \& Brandstrom IJ 2002 Matrix remodeling in the ovary: regulation and functional role of the plasminogen activator and matrix metalloproteinase systems. Molecular and Cellular Endocrinology 187 29-38.

Peters MW, Pursley JR \& Smith GW 2004 Inhibition of intrafollicular $\mathrm{PGE}_{2}$ synthesis and ovulation following ultrasound-mediated intrafollicular injection of the selective cyclooxygenase-2 inhibitor NS398 in cattle. Journal of Animal Science 82 1656-1662.

Plow EF, Freaney DE, Plescia J \& Miles LA 1986 The plasminogen system and cell surfaces: evidence for plasminogen and urokinase receptors on the same cell type. Journal of Cell Biology 103 $2411-2420$

Pursley JR, Mee MO \& Wiltbank MC 1995 Synchronization of ovulation in dairy cows using $\mathrm{PGF}_{2 \text { alpha }}$ and $\mathrm{GnRH}$. Theriogenology 44 915-923.

Pursley JR, Kosorok MR \& Wiltbank MC 1997 Reproductive management of lactating dairy cows using synchronization of ovulation. Journal of Dairy Science 80 301-306.

Robker RL, Russell DL, Yoshioka S, Sharma SC, Lydon JP, O'Malley BW, Espey LL \& Richards JS 2000 Ovulation: a multi-gene, multistep process. Steroids $65559-570$.
Simpson KS, Komar CM \& Curry TE Jr 2003 Localization and expression of tissue inhibitor of metalloproteinase- 4 in the immature gonadotropin-stimulated and adult rat ovary. Biology of Reproduction $68214-221$.

Sirois J 1994 Induction of prostaglandin endoperoxide synthase-2 by human chorionic gonadotropin in bovine preovulatory follicles in vivo. Endocrinology $135841-848$.

Sirois J \& Dore M 1997 The late induction of prostaglandin G/H synthase-2 in equine preovulatory follicles supports its role as a determinant of the ovulatory process. Endocrinology 138 $4427-4434$

Sirois J, Simmons DL \& Richards JS 1992 Hormonal regulation of messenger ribonucleic acid encoding a novel isoform of prostaglandin endoperoxide $\mathrm{H}$ synthase in rat preovulatory follicles. Induction in vivo and in vitro. Journal of Biological Chemistry 267 11586-11592.

Smith GW, Juengel JL, McLntush EW, Youngquist RS, Garverick HA \& Smith MF 1996 Ontogenies of messenger RNA encoding tissue inhibitor of metalloproteinases 1 and 2 within bovine periovulatory follicles and luteal tissue. Domestic Animal Endocrinology 13 151-160.

Smith MF, Ricke WA, Bakke LJ, Dow MP \& Smith GW 2002 Ovarian tissue remodeling: role of matrix metalloproteinases and their inhibitors. Molecular and Cellular Endocrinology 191 45-56.

Sogn JH, Curry TE Jr, Brannstrom M, Lemaire WJ, Koos RD, Papkoff H \& Janson PO 1987 Inhibition of follicle-stimulating hormoneinduced ovulation by indomethacin in the perfused rat ovary. Biology of Reproduction 36 536-542.

Strickland S \& Beers WH 1976 Studies on the role of plasminogen activator in ovulation. In vitro response of granulosa cells to gonadotropins, cyclic nucleotides, and prostaglandins. Journal of Biological Chemistry 251 5694-5702.

Tegeder I, Pfeilschifter J \& Geisslinger G 2001 Cyclooxygenaseindependent actions of cyclooxygenase inhibitors. FASEB Journal 15 2057-2072.

Tsafriri A \& Reich R 1999 Molecular aspects of mammalian ovulation. Experimental and Clinical Endocrinology and Diabetes 107 1-11.

Tsafriri A, Lindner HR, Zor U \& Lamprecht SA 1972 Physiological role of prostaglandins in the induction of ovulation. Prostaglandins $21-10$.

Tsai SJ, Wiltbank MC \& Bodensteiner KJ 1996 Distinct mechanisms regulate induction of messenger ribonucleic acid for prostaglandin (PG) G/H synthase-2, PGE (EP3) receptor, and $\mathrm{PGF}_{2}$ alpha receptor in bovine preovulatory follicles. Endocrinology $1373348-3355$.

Weinreb RN, Lindsey JD, Marchenko G, Marchenko N, Angert M \& Strongin A 2004 Prostaglandin FP agonists alter metalloproteinase gene expression in sclera. Investigative Ophthalmology and Visual Science 45 4368-4377.

Young DA, Phillips BW, Lundy C, Nuttall RK, Hogan A, Schultz GA, Leco KJ, Clark IM \& Edwards DR 2002 Identification of an initiator-like element essential for the expression of the tissue inhibitor of metalloproteinases-4 (Timp-4) gene. Biochemical Journal 364 89-99.

Received 12 August 2005

First decision 27 September 2005

Revised manuscript received 13 November 2005

Accepted 15 December 2005 